Fecha de recepción: abril 2019

Fecha de aceptación: octubre 2019

Versión final: marzo 2020

\section{Changing the Rules of the Game: Sustainable Product Service Systems and Manufacturing in the Fashion Industry}

Noël Palomo-Lovinski ${ }^{\star}$ and Steven Faerm ${ }^{\star *}$

\begin{abstract}
The fashion industry is based on a bygone era in which time is linear and place is specific. This lack of relevancy results in global apparel production that is increasingly inefficient and destructive. The harmful practices of fashion manufacturing industry are no longer permissible in an age that has the knowledge capacity and technological innovations to avoid environmental damage and human inequalities. The deleterious manufacturing practices performed in developing countries contribute to the industry being under continued scrutiny, yet intensifying expectations for fast-paced delivery are at the root of these harmful practices. There is a tacit acknowledgement among fashion industry pundits that historical examples of manufacturing and commerce in the United States do not meet the demands of a society accustomed to instant access, constant change, and low prices. These slower and more traditional models of manufacturing and commerce will increasingly impede profitability in the contemporary marketplace as environmental and social issues continue.

Thus, the fashion industry is in a state flux. Simultaneously, it must decrease destructive practices within the life cycle of clothing while remaining financially sustainable. This binary relationship elicits key questions that can help direct the industry toward a better future. What are the possibilities of domestic apparel manufacturing that utilizes innovative production methods, communication technology, and service systems that, in turn, encourage holistic, sustainable practices? What are the possibilities for and needs of designers who want to take full advantage of an evolving relationship between consumers and designers? In this study, particular attention is paid to new systems of production and distribution that will change the role of fashion designers for the future.
\end{abstract}

Key words: sustainability - fashion design - product service systems - manufacturing technology.

[Abstracts in spanish and portuguese on pages 225-226]

${ }^{(*)}$ Noël Palomo-Lovinski is an Associate Professor at Kent State University in Ohio. She received her B.F.A. in Fashion Design from Parsons School of Design, M.A. in Visual Culture from New York University, and M.F.A. in Textiles from Kent State University. Noël's research focus concerns design responsibility and sustainable practice, future needs of fashion design education, and the relationship between culture and design. 
${ }^{(*)}$ Steven Faerm is an Associate Professor of Fashion Design at Parsons School of Design (Program Director, BFA Fashion Design, 2007-2011). A Parsons alumnus (94') and Designer of the Year Nominee, he began teaching in 1998 while working for designers such as Marc Jacobs, Donna Karan, and Kenneth Richard. He has been recognized for his teaching by winning "The University Distinguished Teaching Award" and The School's "Teaching Excellence Award."

Steven has created college- and pre-college programs and courses for Parsons and other leading international institutions, and has served on academic review boards for Rhode Island School of Design, Pratt Institute, Virginia Commonwealth Institute (VCU), Otis College of Art and Design, and Marist College. He has taught and lectured for institutions including Harvard University, Massachusetts Institute of Technology (MIT), Brown University, Donghua University in Shanghai, The University of Palermo (UP) in Buenos Aires, and The Spero Villioti School in South Africa. Since 2012, he has co-produced an academic journal dedicated to design education between Parsons and UP.

His publications include two books that are featured on international college-level required reading lists and available in seven languages: Fashion Design Course: Principles Practices, and Techniques and Creating a Successful Fashion Collection: Everything You Need to Develop a Great Line and Portfolio. He is currently writing a third book about design education and pedagogy while publishing ongoing research studies in academic journals and serving as a consultant for five publishing houses.

Areas of scholarship and research included the future of art and design education, pedagogy, and student development.

\section{Introduction}

Another example of our intellectual difficulty in thinking simultaneously about continuity and discontinuity, local and global, place and non-place, emerges in art and artistic creation in general. If the relation between artistic creation and our history is difficult to pin down these days, it is precisely because time is accelerating and, as if it were, evading us, and because the overlaying of temporal language by special language, the primacy of code, which prescribes behavior, over the symbolic, which constructs relations, shapes the conditions of artistic creation.

—Marc Augé, 2008, XVII

Our conceptions of time and place have been irrevocably changed by technology, yet the international fashion industry's practices remain steadfast and unadjusted to these new models. In today's global marketplace, many first-world consumers can buy any product they want, when they want it, how they want it, from virtually any source and location in the world, all for a relatively low retail cost. The antiquated and slower-paced methods and processes of domestic manufacturing that were prevalent in the nineteenth and twentieth centuries have been replaced with a crisscrossing global network of highly accelerated 
manufacturing that demands more and more materials that, in turn, rapidly deplete the earth of its resources. These environmental demands simultaneously strain an immense workforce that makes, distributes, and transports vast quantities of manufactured goods all over the globe -often under limited worker's rights, unethical business practices, and dangerous factory conditions (Fletcher, 2008).

The result is a hyper-accelerated manufacturing and distribution system that creates and seeks to satiate the consumer's unquenchable and rapacious desire for novelty. Yet, the consumer's sense of novelty is fleeting and vague, thus encouraging a nefarious cycle of increased acceleration that further escalates environmental damage and broadens the divide between the "haves" and the "have-nots." A concerted effort has been made by those concerned with this growing environmental and ethical dilemma to find solutions that promote a sustainable fashion industry and a flourishing economy -but not at the expense of the larger ecosystem or society itself.

Possible solutions may come in the form of Product Service Systems (PSS) that take advantage of locality and promotes opportunities for an extended relationship between the consumer, the product, and -in select systems models- the designer. PSS may gain appeal and subsequent implementation due to several factors that include mounting interest in domestic apparel manufacturing (Lee, Levy, Fen, \& Yap, 2015), production machinery innovations that encourage small batch production, and the ubiquitous nature of communication technology that enables garment production from seemingly anywhere in the world. This proposed network of an apparel design, production, manufacturing, retail, and disposal system would create an alternative to the fashion industry's current practices that undermine efforts in sustainability, while leveraging the geography and human capital of the U.S.

This paper discusses global and local manufacturing as it relates to the current and evolving fashion industry. A literature review of current PSS models is provided and followed by the authors' proposal for Sustainable PSS (SPSS) that enhances the PSS model. This paper offers a speculative SPSS construct as a reproducible closed-loop scenario that takes advantage of time and place as contextualized within a global society dominated by technology.

\section{Global and Local Manufacturing}

Throughout the twentieth century, most of what Americans wore was made in the U.S. (Novellino, 2015). Legislation - such as the North American Free Trade Agreement (NAFTA) - erased import duties, and by the 1990s, less than 3 percent of the clothing worn in the United States was American-made (Clifford, 2013; Novellino, 2015). To remain competitive, U.S. retailers relocated their manufacturing overseas where labor was less expensive and environmental protection and human rights laws were lax. Retailers were then able to offer cheaper clothing, resulting in higher sales volumes and accelerated manufacturing that met inflated demand (Kunz \& Garner, 2011).

After the shift to overseas manufacturing, access to extensive fashion imagery on Internet search engines worldwide has permanently sped up the rate of visual consumption. This imagery, accessible around the world, creates a heightened awareness and subsequent 
demand for fashion from viewers. This has led to unprecedented rates of consumption that retailers respond to with great zeal. Fast-fashion retailers, including Zara, Hennes \& Mauritz (H\&M), and Forever 21, use "just-in-time" or "postponement manufacturing" practices (Christopher, 2000), as well as "on-the-floor" and social-media sales intelligence that mitigates the impact of the shifting balance of price-versus-style demands (Chaudhry \& Hodge, 2012; Christopher, 2000). Additionally, these retailers stimulate consumption by using short runs to engender a sense of scarcity and "grab it while you can" consumer psychology. For example, Zara delivers a new shipment of merchandise every two weeks, thus increasing sell rates, decreasing overstocks, and forcing sale prices (Christopher, 2000). Many industry researchers and analysts predict the acceleration of the fashion cycle will only increase, and that customers will expect increased customization (Amed, Berg, Brantberg, Hedrich, Leon, \& Young, 2016). Simultaneously, as these fast-fashion retailers and manufacturers compete to be faster in style turnover, they must also lower prices to stay competitive. Consumers now pay less for more clothing (Kunz \& Garner, 2011). This fact alone suggests a finite time period before costs outweigh financial returns (Joy, Sherry, Venkatesh, Wang, \& Chan, 2012; Jung \& Jin, 2014) and, indeed, in 2016 the fashion industry suffered another year of slight sales growth, slowing to a mere 2 to 3 percent (Amed et al., 2016).

Unmitigated consumption, driven by style websites, blogs, and the very nature of fastfashion apparel itself, increasingly calls into question what we have traditionally seen as trends. Trends have always marked time in fashion (e.g. flappers in the 1920s and the miniskirt in the 1960s), yet as the Internet catalogues an infinite simulacrum of fashion images, time is rendered irrelevant. Similarly, place -or time as it relates to place- is no longer meaningful since international fashion brands are required to concurrently create items for diverse international marketplaces. Design houses routinely feature a range of fabrics to service all seasons in all parts of the globe, within one collection or seasonal delivery. All fashion companies -from those in the high luxury markets to the most inexpensive fast-fashion retailers- have unmitigated expectations of constant, fast-paced aesthetic changes. This "break-neck" pace of the global fashion industry promotes subjective obsolescence and decreases the probability of true innovation beyond its most basic form. Several initiatives and trends fomenting within the cultural zeitgeist point to new opportunities for change (Soper, 2008; Shah, 2013). Traditional paradigms -such as those of the automobile industry- have shifted, allowing specific innovations or workload allocation to diffuse to local sites rather than a single manufacturing center (Florida, 2002). Food retail shops or restaurants selling produce from international, national, and local sources satisfy local tastes, and offset overhead costs and supply needs while lessening their carbon footprint. Local products inspiring deep loyalty and pride within the U.S. can be seen in the ascendance of craft beer within the American market. Nielsen, the global measurement and data analytics company, states the "dollar sales growth in the craft realm ranged between just over 15\% to just over 18\% from 2013 through early 2016, well above the $1.3 \%-3.5 \%$ posted by the overall beer category (excluding flavored malt beverages, ciders and seltzers)" (Nielsen, n.p.).

The slogan "Buy Local" initially may have referred to locally produced food or handmade products, but is now used for clothing and fashion products as well. Web directories and 
services, such as Maker's Row, connect local manufacturing or production services with entrepreneurial designers. Several incubation and accelerator programs promote new approaches to retail, start-ups, and artisanal product manufacturing. Many easily accessed documentaries and books also highlight the environmental and social concerns associated with the fashion industry. Consumers, therefore, are increasingly being asked to consider the ethics of purchasing, and the implications of unmitigated consumerism of fast-fashion apparel made in environmentally and/or socially harmful conditions (Soper, 2008; Fletcher, 2008).

\section{Need for Change}

The global fashion industry is ever changing, due to increasing environmental and social issues. These issues are, in turn, coupled with decreasing profitability. This combination creates opportunities for a reimagined set of best practices. Advances in communication, information, and manufacturing technologies have facilitated a change in the geography of production (Labrianidis, Kalantaridis, \& Dunford 2011) from the U.S. outward. Centralized manufacturing and trade from one, singular urban center -as was the case of New York City's Garment District- is no longer useful due to its relative unprofitability.

Global fashion capitals, such as New York, Milan, or Paris, are no longer the monoliths of design. Traditionally, creative resources -such as visual imagery- have been found almost exclusively in physical locations, such as museums, galleries, and shops. Now, online resources such as Google, Pinterest, and YouTube are free and accessible to anyone, located virtually anywhere on Earth. These Internet-based fashion hubs offer audiences tremendous opportunities to find inspiration. They enable creative individuals around the world to inspire others and instigate new trends. There are now viable opportunities to offer a wider spectrum of choice, both to those working in the fashion industry and to the consumers who buy from it.

The need for greater efficiency and agility is a compelling argument (Hagerty \& Magnier, 2015) for the development of more efficient systems of design, production, distribution, and disposal. A company's economic longevity is intricately tied to its ability to facilitate consistent change in products and processes, and generate new opportunities based on constant communications with their customers (Florida 2002). These demands of efficiency dictate a revaluation of traditional practices in the fashion industry that increasingly strain the environment.

One example of the inefficient practices that concurrently result in environmental damage is that of cotton production in Texas. The U.S. state is the leading cotton-producing state in the nation and the global market, having produced 16 million bales of cotton in 2014 (Novellino, 2015). Despite this rich, local resource, the U.S. ships most of its cotton overseas to be made into textiles, apparel, and other products. The goods are shipped back to the U.S. for Americans to purchase. Once these products are discarded, most of goods that are not discarded as trash are shipped to developing countries as second-hand clothing (Fletcher, 2008). Throughout the current set of supply chain practices, efficiency and agility are increasingly harder to achieve, due in part to the mammoth scale of the industry 
and its hyper-accelerated speed that prioritizes output and delivery over best sustainable practices and waste reduction. This realization has inspired many to consider alternative ways of doing business.

\section{Product Service Systems}

Product Service Systems (PSS) are an extension of service and potential contact beyond a product's point of sale. PSS as a business concept has been around since the 1990s. Since then, PSS has had increasing applications within the fashion industry (Cheschin, 2013; Vezzoli, Chechin, Diehl \& Kohtala, 2015). PSS is closely connected to increased attention to the user experience and creative narrative of a brand in support of differentiation within the competitive product market (Jacob \& Ulaga, 2008). It has been pointed out that PSS does not guarantee sustainable practice and, in fact, has the potential to exacerbate the very issues around sustainability (Rexfelt \& Hiort af Ornäs, 2009; Ceschin, 2013).

The Sustainable Product Service Systems (SPSS) that have thus far been proposed have focused on renting, redesign or alterations, co-design, and wardrobe consultation as well as "take back" disposal (Armstrong et al., 2014; Gelbmann \& Hammerl, 2015). However, initial consumer perceptions and receptivity investigations into SPSS suggest that many consumers are hesitant to adopt SPSS due to perceived decreases in usability, or an increase of costs, and a sense of unfamiliarity with how any of these services might work within the supply chain (Armstrong, Niinimäki, Kujala, Karell, \& Lang, 2014; Vezzoli et al., 2015). As SPSS becomes a greater part of the market, and with a significant increase in its available advantages, this hesitation is expected to lessen. There is also strong evidence that there are many internal barriers within existing companies to SPSS, since it means financial investment in major reorganizations of production, distribution, and disposal systems, as well as requiring a shift in mindset among market participants (Martinez, Bastl, Kingston, \& Evans, 2009; Vezzoli et al., 2015). The authors believe the proposed SPSS offers a distinct advantage to the next generation of designers, retailers, and the fashion industry.

\section{Sustainable Product Service System Proposal}

A primary objective of SPSS would be to reduce the extent of carbon footprint produced through the manufacturing and distribution of products. To achieve this, an SPSS would require several geographically dispersed hubs, or outposts, most likely in larger cities for ideal operation. These hubs would feature design departments, production rooms, manufacturing, retail, and "take-back centers" that would enable a closed-loop system within the market. Through SPSS, market participants would have a greater sense of connection between consumer, designer, and manufacturer (Vezzoli et al., 2015). Further, an SPSS that is specific to the community or region would encourage trust due to the greater sense of transparency, access, and collaboration it provides consumers. The local SPSS will also be an essential part of sustainable consumption behavior since tangible environmental damage or social malfeasance is harder to ignore, as was recently shown through a study 
conducted in New Zealand (Lee, Levy, Fen \& Yap, 2015). It is essential however that the cost associated with any SPSS would not be prohibitive and would rely on alternative or different modes of production.

Mudambi (2008) notes that vertical integration of manufacturing processes within one locality is a crucial attribute for market participants to gain future competitive advantages. Currently, local small businesses, which usually have a slower rate of fashion production, cannot take advantage of the larger resource savings resulting from the economies of scale inherent in SPSS (Jung \& Jin, 2014). This concept can be illustrated with the example of a proposed SPSS structure that spans several U.S. states, supports the macro-acquisition of goods related to scale, and additionally enables interaction on a micro-level with consumers and communities. In such an SPSS structure, greige (undyed) fabric, equipment, machines, and other overhead costs would be consolidated to achieve greater savings and efficiencies due to economies of scale. Each hub would interact as links in the web of a national brand, yet serve as local, individualized places.

The SPSS focus on dispersing apparel production would also benefit external and supporting businesses within each included community. Evidence suggests that the advancement and economic sustainability of any community is predicated on new businesses or high-tech industry fostering industrial linkages with both business markets and government, and alternative business structures within a larger infrastructure (Glasmeier, 1988). As an example of these types of linkages, McRobbie (2013) cites government initiatives in Berlin which provide training and education around product creation to underrepresented and migrant populations. As a result, these workers became productive members of society while also supporting burgeoning fashion enterprises which contribute to Berlin's overall economy. A strong, viable community and economy demands environmentally and socially sustainable best practices that must be fundamentally inherent in any new fashion business (Fiksel, 2003). The essential factor in a future sustainable fashion system is that those very same populations that have traditionally worked in low-wage or dangerous conditions would be able to take on greater responsibilities, with a wider set of creative contributions, and with increased wages.

\section{Design}

Designer expectations and requirements are quickly changing to reflect the fluctuating apparel market. The role of the fashion designer as an "all-knowing style dictator" no longer works in an age predicated on constant change, simultaneous trends, and increasingly discerning consumers (Craik, 2009; Partington, 2014). Retailers rely on surveys and data-mining sources to accurately gauge what is important to consumers (Meyer, 2001). This data should be fully utilized to implement initiatives which would attract and incentivize consumers while simultaneously supporting specific sustainability issues that fashion companies believe are strategically important for future success. Meyer (2001) suggests that sustainable fashion is not evaluated solely on its environmental impact by most consumers, but rather on durability, look, and price. It is essential, then, that the industry create sustainable environmental and social actions in conjunction with economic sustainability to achieve success in this new world. 
To best incorporate the needs and constraints of designing within a sustainable paradigm, designers must specialize in one of two streams of production. For example, a proposed SPSS could feature a group of designers that would create small-batch collections based on the needs and wants of existing customers through the local retail outlet. These designers would also help propagate creative style directives inspired by aesthetic or cultural research. These designers would target the wide range of age, socio-economic, and cultural requirements, as well as the physical environment of the specific locality in which they work. The retail and take-back centers would provide useful and immediate information to design and production. Cross-pollination between departments or activity fields may be improved due to linked specializations, such as design with marketing or sales and after-sales services (Mudambi, 2008).

In conjunction with this first group of designers, a second group's primary objective would be responsible for designing clothing returned to the take-back center. This clothing would only be from the company group to ensure sustainable fibers and recyclable color and finishes, as well as quality of fibers and workmanship. Each returned garment would be evaluated for recyclability, with gently used or newly mended clothing resold. Clothing with a major flaw prohibiting resale would be disassembled or re-utilized for an upcycled garment. For those garments beyond repair or already upcycled, the fiber would be shredded or composted. Additionally, this second group of designers would interact with the communities offering upcycling services, in which consumers could actively participate. A consumer could make an appointment with a designer, allowing extended use of garments due to alterations instigated by the customer.

\section{Production}

The fast fashion retailer Zara has become the gold standard of fashion businesses; 85 percent of Zara merchandise is sold at full price, while the industry standard is generally 60 to 70 percent $(\mathrm{Lu}, 2014)$. Upwards of 60 percent of Zara clothing is made near company headquarters in Spain, utilizing highly automated factories (Christopher, 2000). Zara has become the foremost example of how technology can positively affect the future of the fashion industry. Digitization of the supply chain increases efficiency, lowers procurement costs, and allows for greater connection and customization (Amed et al., 2016). Commonly used materials are tracked, and fabrics are held in greige so that looks can quickly change based on fluctuating consumer interest (Christopher, 2000). Generic shapes are held in postponement until specific style details are known, allowing for increased mass customization and a nod to momentary trends.

Improved cost efficiency and responsiveness to consumer needs opens a revaluation of production. Amed et al. (2016) suggest that an increase in mechanization and technological advancements is the only way to successfully create a sustainable (environmentally, economically, and socially) manufacturing system. Within the localized scenario proposed here, small-batch, mechanized manufacturing would accommodate controlled cycle acceleration and any specific customer needs, while emphasizing a local and sustainable practice. Product would be carefully evaluated and considered to ensure products are made for specific consumer needs. 


\section{Educational Needs in Support of SPSS}

As the fashion industry is being forced to meet the new construct of declining natural resources, increasing environmental pollution and climate change, as well as an increased interest in accountability by customers, so too must higher education in fashion programs consider how best to meet the challenges of the twenty-first century (Wolf \& Rhee, 2009). Traditional design programs rooted in Bauhaus ideologies must give way to advanced curricula that promotes a greater understanding of the interconnectivity design plays in the world. Lydia Matthews, Professor of Visual Culture at Parsons School of Design, describes this new direction by stating:

[Designers] recognize that they need to have an understanding of world systems, whether they're economic, social, ethnographic, or cultural. At the same time, social scientists (...) are beginning to understand that the systems they work with are in fact designed and that there's a fundamental need to communicate visually and materially across cultures and in a globalized condition (Agid, 2008, p. 13).

To support this need -particularly in context of SPSSs- new initiatives in design education must increasingly prioritize curricula that prepare students for their new role - from one who is a "style dictator" to one that works collaboratively in cross-disciplinary teams. Disciplinary overlaps and adjacencies will allow students to better understand how their practice and skillsets situate themselves within a broader context. Simultaneously, the approach will also allow the designer to interface with new methodologies that may then be synthesized with their own specific approaches. A more porous relationship with other fields must occur in order for students to look beyond the traditional "silo" of fashion design. As Zimmerman (2003) notes:

While design research comes in many forms, ranging from quantitative market research to personal interviews, experimental design analysis and qualitative research, it also represents a willingness to look beyond the immediate concern of crafting a project, as well as an openness to integrating new insights into the design process itself (p. 25).

Thus, the design and business students who have traditionally worked in different spaces -the literal and the figural- must coalesce if the fashion industry is to develop and implement successful SPSSs. The design students will come to understand marketing, consumer relations, and business systems. The business students will gain insights into fashion-specific design processes, sustainability in the garment-making context, and required resources. This shared understanding of the other's discipline, and attendant problems that need solutions, will generate more thoughtful proposals for increasingly successful outcomes.

The authors believe a key principle in this educational model that supports SPSSs will be curricula that teaches students the vital, participatory role consumers can play. In our 
over-abundant and hyper-accelerated world, consumer behaviors have changed exponentially. The over-abundance of the marketplace requires designers to discover the emotional needs of their audience, rather than solely the material needs that have been met, and even over-met (Pink, 2005). Given the increasingly active role the consumer plays -and the decreased role the designer plays as "design dictator"- it is essential for students to be taught how to actively listen and absorb information from their audience while also providing leadership around design problems.

Design education must therefore instill a new series of attributes in students that move well beyond technical acumen and aesthetics. These traits include a consistent openness to design thinking and strategy, and the ability to rely on fundamentally shifting constraints, opportunities, and solutions due to developments in technology and sustainable practices (Wolf \& Rhee, 2009). Students and professionals will have to "comprehend both the problem and the context of the problem and how to design or create solutions that are efficiently and aesthetically desirable for the community" (Van Zandt, 2011, n.p.). There will be a new generation of graduates who possess broader interdisciplinary knowledge with which they can "understand the socio-cultural, political and commercial implications that design can have in the society, and not only the immediate aesthetic, functional and/or structural applications of design" (Muratovski, 2010, p. 385).

\section{Conclusion}

The prescient vision of the fashion industry is shaped by the duality of clear social and environmental harm with the capacity of innovation, change, and motivation to design a better world. This paper considers ways that could engage communities to consider clothing production much like food consumption. The slow food movement encourages local organic farming, thoughtful consumption, and methods of creating more closed loop systems (such as composting). These farmers and farmers' markets encourage community participation and transparency. So too can the consumable product of clothing become locally based with greater concern for the environment and the people it serves.

The proposed Sustainable Product Service System would create a locally considered space that promotes site-specific design, manufacturing, and retail in conjunction with a global perspective, presence, and digital distribution of ideas. The capability of creating such a system is possible; the technology is present and the business systems currently employed are successful. As such, the authors' proposal is an amalgamation of existing concepts and practices that are brought together for a more efficient and beneficial purpose. Supply chain resources would be consolidated for more efficient distribution using the same postponement policies used by Zara. Digital and technological applications within the supply chain would allow a considered approach to individual sales as well as a continued connection to any specific consumer. This proposal seeks to be a part of the community, generating local economies and tailored products that better target and meet consumers' needs. Transparency, education, and interaction would enable designers, manufacturers, and retailers to not only encourage consumers to be more thoughtful consumers, but to also have a better idea of what consumers truly want. Thus, the authors' proposal is part 
of a widespread desire to ameliorate the destructive practices of the fashion industry while continuing a profitable and thriving industry.

\section{Resources}

Agid. S. (2008, fall). Re: Imagining Parsons--How Parsons' new academic structure is shaping design education in the 21st century. Re:D, 26(2), 10-15.

Amed,I., Berg, A., Brantberg,L., Hedrich, S., Leon, J., \& Young, R. (2016). The state of fashion. The Business of Fashion. Retrieved from https://www.businessoffashion.com/ site/uploads/2016/11/The_State_of_Fashion_2017.pdf

Armstrong, C., Niinimaki, K., Kujala, S., Karell, E., \& Lang, C. (2014). Sustainable product service systems for clothing: Exploring consumer perceptions of consumption alternatives. Journal of Cleaner Production, 97, 30-39.

Augé, M. (2008), Non-places: An introduction to supermodernity, New York: Verso.

Ceschin, F. (2013). Critical factors for implementing and diffusing sustainable product service systems: Insights from innovation studies and company's experiences. Journal of Cleaner Production, 45, 74-88.

Chaudhry, H. \& Hodge, G. (2012). Postponement and supply chain structure: Cases from the textile and apparel industry. Journal of Fashion Marketing and Management, 16(1), 64-80.

Clifford, S. (2013, September 19). U.S. textile plants return with floors largely empty of people. The New York Times. Retrieved from www.nytimes.com/2013/09/20/business/ us-textile-factories-return.html?

Christopher, M. (2000). The agile supply chain: Competing in volatile markets. Industrial Marketing and Management, 29, 37-44.

Craik, J. (2009). Fashion: The key concepts, New York: Berg.

Fiksel, J. (2003). Designing resilient, sustainable systems. Environmental Science \& Technology, 37(23), 5330-5339.

Fletcher, K. (2008). Sustainable fashion and textiles: Design journeys. London: Earthscan.

Florida, R. (2002). The learning region. In Gertler, M.S. \& Wolfe, D. (Eds.), Innovation and social learning: Institutional adaption in an era of technological change. New York: Palgrave MacMillan.

Gelbmann, U. \& Hammerl, B. (2015). Integrative re-use systems as innovative business models for devising sustainable product-service-systems. Journal for Cleaner Production, 97, 50-60.

Glasmeier, A. (1988). Factors governing the development of high tech industry agglomerations: A tale of three cities. Regional Studies, 22.4, 287-301.

Jacob, F. \& Ulaga, W. (2008). The transition from product to service in business markets: An agenda for academic inquiry. Industrial Marketing Management, 37, 247-253.

Hagerty, J. \& Magnier, M. (2015, January 13). Companies tiptoe back towards 'made in the USA. The Wall Street Journal. Retrieved from www.wsj.com/articles/companies

Joy, A. Sherry, J., Venkatesh, A., \& Chan, R. (2012). Fast fashion, sustainability, and the ethical appeal of luxury brands. Fashion Theory, 16(3), 273-296. 
Jung, S. \& Jin, B. (2014). A theoretical investigation of slow fashion: Sustainable future of the apparel industry. International Journal of Consumer Studies, 38, 510-519.

Kunz G. \& Garner, M. (2011). Going global: The textile and apparel industry (2 ${ }^{\text {nd }}$ Ed.). New York: Fairchild.

Labrianidis, L., Kalantaridis, C., \& Dunford, M. (2011). Delocalization of economic activity: Agents, places, and industries. Regional Studies, 45.2, 147-151.

Lee, C.K.C., Levy, D.S., \& Yap, C. S. F. (2015). How does the theory of consumption values contribute to place, identity, and sustainable production? International Journal of Consumer Studies, 39, 597-607.

Lu,C. (2014). Zara supply chain analysis: The secret behind Zara's retail success. Retrieved from www.tradegecko.com/blog

Martinez, V., Bastl, M., Kingston, J., \& Evans, S. (2009). Challenges in transforming manufacturing organizations into product service providers. Journal of Manufacturing Technology Management, (21)4, 449-469.

McRobbie, A. (2013). Fashion matters Berlin; City-spaces, women's working lives, new social enterprise? Cultural Studies, 27(6), 982-1010.

Meyer, A. (2001). What's in it for the customers? Successfully marketing green clothes. Business Strategy and the Environment, 10, 317-330.

Mudambi, R. (2008). Location, control, and innovation in knowledge intensive industries. Journal of Economic Geography, 8, 699-725.

Muratovski, M. (2010). Design and design research: The conflict between the principles in design education and practices in industry. Design Principles and Practices: An International Journal, 4(2), 377-386.

The Neilsen Company. (2017, May 15). The state of the U.S. beer market. Retrieved from http:// www.nielsen.com/us/en/insights/reports/2017/the-state-of-the-us-beer-market.html

Novellino, T. (2015, July 2). Made in the USA clothing: Rare but worth it. New York Business Journal. Retrieved from www.bizjournals.com/newyork/.../made-in-the-usa-clothingrare-but-worth-it.html

Partington, A. (2014). Class, clothes, and co-creativity. Clothing Cultures, 1(1),7-21.

Pink, D.H. (2005). A Whole new mind: Why right-brainers will rule the future. New York: Riverhead Books.

Rexfelt, O. \& Hiort af Ornäs, V. (2009). Consumer acceptance of product service systems: Designing for relative advantages and uncertainty reductions. Journal of Manufacturing Technology Management, (20)5, 674-699.

Shah, D. (2013). Happy-nomics. In Brand, J. \& Vos, M. (Eds.), A fashion odyssey: Progress in fashion and sustainability. Arnhem, The Netherlands: ArtEZ Press.

Soper, K. (2008). Alternative hedonism, cultural theory and the role of the aesthetic revisioning. Cultural Studies, 22(5), 567-587.

Van Zandt, D. (2011). Inaugural address. Retrieved from http://www.newschool.edu/leader ship/president/installation/

Vezzoli, C., Ceschin, F., Diehl, J.C. \& Kohtala, C. (2015). New design challenges to widely implement sustainable product service systems. Journal of Cleaner Production, 97, 1-12.

Wolff, L. \& Rhee, J. (2009, May). Is design the new liberal arts? Re:D (Regarding Design),(26)6, 9-13. 
Zimmerman, E. (2003). Creating a culture of design research: methods and perspective. B. Laurel (Ed.). Cambridge: MIT Press

Resumen: La industria de la moda se basa en una época pasada en la que el tiempo era lineal y el lugar específico. Esta falta de relevancia da como resultado una producción global de vestimenta que es cada vez más ineficiente y destructiva. Las prácticas nocivas de la industria de fabricación de moda no son permisibles en una época que tiene la capacidad de conocimiento y las innovaciones tecnológicas para evitar el daño ambiental y las desigualdades humanas. Las prácticas de fabricación perjudiciales realizadas en los países en desarrollo contribuyen a que la industria siga bajo un escrutinio continuo, pero la intensificación de las expectativas de una entrega rápida está en la raíz de estas prácticas dañinas. Existe un reconocimiento tácito entre los expertos de la industria de la moda, donde los ejemplos históricos de fabricación y comercio en los Estados Unidos no satisfacen las demandas de una sociedad acostumbrada al acceso instantáneo, el cambio constante y los precios bajos. Estos modelos más lentos y tradicionales de fabricación y comercio complicarán cada vez más la rentabilidad en el mercado contemporáneo y ambiental, haciendo que los problemas sociales continúen. Por lo tanto, la industria de la moda está en un estado de cambio. Simultáneamente, deben disminuir las prácticas destructivas dentro del ciclo de vida de la vestimenta sin dejar de ser financieramente sostenible. Esta relación binaria provoca preguntas clave que pueden ayudar a dirigir la industria hacia un futuro mejor. ¿Cuáles son las posibilidades de la fabricación de ropa nacional que utiliza métodos de producción innovadores, tecnología de comunicación y sistemas de servicio que, a su vez, fomentan prácticas holísticas y sostenibles? ¿Cuáles son las posibilidades y las necesidades de los diseñadores que desean aprovechar al máximo una relación en crecimiento entre consumidores y diseñadores? En este estudio, se presta especial atención a los nuevos sistemas de producción y distribución que cambiarán el papel de los diseñadores de moda para el futuro.

Palabras clave: Sostenibilidad - diseño de moda - sistemas de servicio de productos - fabricación - tecnología.

Resumo: A indústria da moda é baseada em uma época passada em que o tempo era linear e o local específico. Essa falta de relevância resulta em uma produção global de roupas cada vez mais ineficiente e destrutiva. As práticas danosas da indústria de confecção da moda não são permissíveis em um tempo que tenha a capacidade de conhecimento $\mathrm{e}$ inovações tecnológicas para evitar danos ambientais e desigualdades humanas. Práticas de fabricação prejudiciais nos países em desenvolvimento contribuem para o contínuo escrutínio da indústria, mas a intensificação das expectativas de entrega rápida está na raiz dessas práticas prejudiciais. Há um reconhecimento tácito entre os especialistas da indústria da moda, onde exemplos históricos de manufatura e comércio nos Estados Unidos não atendem às demandas de uma sociedade acostumada ao acesso instantâneo, às constantes mudanças e aos baixos preços. Esses modelos mais lentos e tradicionais de fa- 
bricação e comércio complicarão cada vez mais a lucratividade no mercado contemporâneo e ambiental, fazendo com que os problemas sociais continuem. Portanto, a indústria da moda está em estado de mudança. Simultaneamente, as práticas destrutivas dentro do ciclo de vida das roupas devem diminuir, permanecendo financeiramente sustentáveis. Esse relacionamento binário levanta questões-chave que podem ajudar a liderar a indústria em direção a um futuro melhor. Quais são as possibilidades de fabricação de vestuário nacional que utiliza métodos de produção inovadores, tecnologia de comunicação e sistemas de serviços que, por sua vez, promovem práticas holísticas e sustentáveis? Quais são as possibilidades e necessidades de designers que desejam aproveitar ao máximo um relacionamento crescente entre consumidores e designers? Neste estudo, atenção especial é dada aos novos sistemas de produção e distribuição que mudarão o papel dos designers de moda para o futuro.

Palavras chave: Sustentabilidade - design de moda - sistemas de serviços de produtos fabricação - tecnologia.

[Las traducciones de los abstracts fueron supervisadas por el autor de cada artículo] 